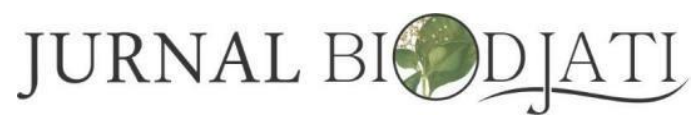

http://journal.uinsgd.ac.id/index.php/biodjati

\title{
PENGARUH PUPUK HAYATI DAN ANORGANIK TERHADAP POPULASI BAKTERI PELARUT FOSFAT, KANDUNGAN FOSFAT (P), DAN HASIL TOMAT HIDROPONIK
}

\author{
Adhitiya Rana ${ }^{1}$, Mieke Rochimi Setiawati ${ }^{2}$, Abraham Suriadikusumah ${ }^{3}$ \\ ${ }^{1,2,3}$ Fakultas Pertanian, Universitas Padjadjaran
}

Diterima : 15 Maret 2018

Disetujui :22 Mei 2018

Publish : 31 Mei 2018

Jl. Raya Jatinangor $\mathrm{Km}$.

21, Sumedang 45363 Jawa

Barat, Indonesia

e-mail

Iadhitiya.rana@gmail.com, ${ }^{2}$ mie

kesetiawati@yahoo.com,

3abrahamsur@yahoo.co.id

e-ISSN : 2541-4208

p-ISSN : 2548-1606
Abstrak. Pada sistem hidroponik, pemberian pupuk anorganik dan pupuk hayati dilakukan untuk meningkatkan hasil tanaman karena pupuk anorganik menyediakan unsur hara dan pupuk hayati menghasilkan fitohormon yang meningkatkan pertumbuhan tanaman. Penelitian ini bertujuan untuk mengetahui pengaruh pemberian pupuk hayati yang dikombinasikan dengan pupuk anorganik terhadap populasi bakteri pelarut fosfat, kandungan fosfat $(P)$ dan hasil tanaman tomat. Penelitian ini dilakukan menggunakan rancangan acak kelompok (RAK) dengan 7 perlakuan kombinasi pupuk anorganik (konsentrasi 100\%, 75\%, dan $50 \%$ ), pupuk hayati (konsentrasi 100\%, 75\%, 50\%, dan 25\%) 4 ulangan. Data yang diperoleh dianalisis secara statistik untuk melihat pengaruh perlakuan. Hasil percobaan menunjukkan bahwa kombinasi pupuk anorganik dan pupuk hayati menunjukkan hasil yang tidak berbeda nyata terhadap populasi bakteri pelarut fosfat, kandungan $P$, dan hasil tanaman tomat pada sistem hidroponik.

Kata kunci : hidroponik, pupuk hayati, tanaman tomat.

\begin{abstract}
At hydroponic systems, the granting of inorganic fertilizer and biofertilizer is done to increase crop yield due to inorganic fertilizers provide nutrient elements and biofertilizer produce fitohormon that improve plant growth. This research aims to know the effect of biofertilizer on phosphate solubilizing bacteria's population, phosphate $(P)$ content of plant, and yield of tomatoes plant in a hydroponic systems. This research was conducted using Randomized Block Designwith 7 treatments combination consisted of inorganic fertilizer (concentration 100\%, $75 \%$ and $50 \%)$ and biofertilizer $(100 \%, 75 \%, 50 \%$, and $25 \%)$ with 4 replications. The result showed that the combination of inorganic fertilizer and bifertilizer on tomatoes plant in hydroponics system does not show the significant result on phosphatesolubilizing bacteria's population, phosphate content of plant, and yield of tomatoes plant (Lycopersicon esculentum Mill.).
\end{abstract}

Key words : hydroponic, biofertilizer, tomatoes plant.

\section{Cara Sitasi}

Rana, A., Setiawati, M. R. \& Suriadikusumah, A. (2018). Pengaruh Pupuk Hayati dan Anorganik Terhadap Populasi Bakteri Pelarut Fosfat. Kandungan Fosfat (P) dan Hasil Tomat Hidroponik. Jurnal Biodjati, 3 (1), $15-22$. 


\section{JURNAL BIODJATI}

http://journal.uinsgd.ac.id/index.php/biodjati

\section{PENDAHULUAN}

Tanaman tomat (Lycopersicon esculentum Mill.) merupakan salah satu tanaman penghasil komoditas hortikultura yang memiliki berbagai kandungan bermanfaat seperti vitamin A, C, karbohidrat, lemak (Sastrosiswojo et al., 2000), serta antioksidan yang dapat mencegah penyakit kanker (Miller et al., 2002). Produksi buah tomat di Indonesia pada tahun 2015 adalah sebesar 878.741 ton. Jumlah ini menurun dibandingkan produksi buah tomat pada tahun 2014 yang mencapai 915.987 ton (Kementrian Pertanian, 2015).

Produktivitas tomat di Indonesia masih tergolong rendah. Pada tahun 2010 produktivitas tomat di Indonesia baru mencapai 14,58 ton $\mathrm{ha}^{-1}$ dibandingkan Amerika Serikat yang telah mencapai 69,40 ton ha ${ }^{-1}$ di tahun 2002 (Marliah et al., 2012). Rendahnya produktivitas tomat dapat disebabkan berbagai faktor seperti perubahan iklim global, gangguan organisme pengganggu tanaman, penggunaan varietas yang tidak cocok, dan penurunan daya dukung lahan (Wasonowati, 2011).

Keberadaan lahan juga sangat penting dalam mendukung produksi tomat (Ekaputri, 2008). Lahan produktif semakin sulit ditemukan karena tergeser oleh kegiatan industri terutama di daerah perkotaan. Salah satu metode yang dapat diterapkan untuk meningkatkan hasil tanaman tomat dengan lahan yang terbatas yaitu dengan menerapkan sistem hidroponik.

Hidroponik merupakan teknik bertanam tanpa menggunakan tanah sebagai media tanamnya (Lingga, 2009). Teknik ini dapat meningkatkan hasil tanaman sampai sepuluh kali per satuan luas apabila dibandingkan dengan teknik konvensional (Basuki, 2008). Hidroponik dapat menggunakan media arang sekam, rockwool, batu apung, pasir, kerikil, dan media air serta udara (Wasonowati, 2011). Menurut Fitriani et al (2017) penggunaan sistem dapat meningkatkan hasil tanaman tomat.

Dalam sistem hidroponik, ketersediaan unsur hara dijaga melalui pemupukan berupa penambahan larutan nutrisi ke dalam media tanam. Larutan nutrisi yang digunakan merupakan pupuk anorganik yang terdiri atas garam-garam mineral (Lingga, 2009). Pencarian dosis yang paling baik khususnya bagi tanaman tomat masih terus dilakukan karena sering kali terjadi pemberian pupuk yang berlebihan dan menyebabkan penggunaan pupuk anorganik menjadi boros (Fitriani et al., 2017).

Salah satu cara untuk meningkatkan efisiensi pemberian pupuk anorganik adalah dengan menggunakan pupuk hayati. Pupuk hayati merupakan pupuk yang berisikan mikroba hidup. Salah satu contohnya adalah Bion-Up produksi Laboratorium Biologi Tanah Unpad yang terdiri dari campuran isolat Azotobacter sp, Azospirilium sp, bakteri endofitik, dan mikroba (bakteri dan jamur) pelarut fosfat. Pemberian pupuk hayati dapat membantu meningkatkan pertumbuhan tanaman. Hal ini karena pupuk hayati mengandung Plant Growth Promoting Rhizobacteria (PGPR) hidup (Setiawati et al., 2014).

Fungsi PGPR bagi tanaman yaitu membantu menyediakan hara bagi tanaman serta mampu mengurangi penyakit atau kerusakan oleh serangga. Pupuk hayati juga menghasilkan fitohormon yang dapat meningkatkan pertumbuhan tanaman. Sebagai contoh, bakteri pelarut fosfat (BPF) seperti Bacillus sp dan Pseudomonas sp yang terkandung dalam pupuk hayati memiliki kemampuan untuk menghasilkan fitohormon seperti auksin, giberelin, dan sitokinin (Setiawati et al., 2014). 


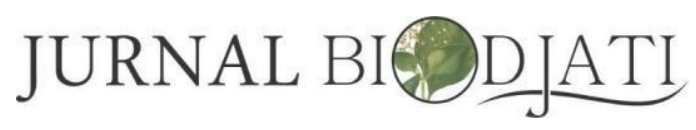

http://journal.uinsgd.ac.id/index.php/biodjati

Berdasarkan uraian tersebut, perlu dilakukan penelitian mengenai pengaruh pemberian pupuk anorganik dan pupuk hayati pada tanaman tomat dengan sistem hidroponik. Hasil penelitian ini diharapkan dapat bermanfaat untuk meningkatkan produktivitas tomat khususnya dengan sistem hidroponik.

\section{BAHAN DAN METODE}

Penelitian ini dilaksanakan pada bulan Agustus sampai dengan November 2017. Tempat penelitian dilakukan di Laboratorium Biologi Tanah, Laboratorium D3, Laboratorium Kesuburan Tanah dan Nutrisi Tanaman, dan Rumah Kaca Fakultas Pertanian Universitas Padjadjaran, Jatinangor, Kabupaten Sumedang.

Bahan yang digunakan dalam penelitian yaitu arang sekam, cocopeat, air, polybag, benih tomat varietas Martha, pupuk anorganik produksi laboratorium kultur terkendali Universitas Padjadjaran, pupuk hayati BionUp produksi Laboratorium Biologi Tanah Unpad yang terdiri dari campuran isolat Azotobacter sp, Azospirilium sp, bakteri endofitik, dan mikroba (bakteri dan jamur) pelarut fosfat.

Metode penelitian menggunakan metode eksperimen Rancangan Acak Kelompok (RAK), yang diulang sebanyak 4 kali. Kombinasi perlakuan terdiri dari perlakuan A $=100 \%$ pupuk anorganik (4 L larutan induk/50 $\mathrm{L}$ air) sebagai kontrol, perlakuan $\mathrm{B}=50 \%$ pupuk anorganik (2 L larutan induk/50 L air) + $100 \%$ pupuk hayati (10 mL dengan kepadatan $\left.4,5 \times 10^{8} \mathrm{CFU} / \mathrm{mL}\right)$, perlakuan $\mathrm{C}=75 \%$ pupuk anorganik (3 L larutan induk/50 L air) $+100 \%$ pupuk hayati $(10 \mathrm{~mL}$ dengan kepadatan $\left.4,5 \times 10^{8} \mathrm{CFU} / \mathrm{mL}\right)$, perlakuan $\mathrm{D}=100 \%$ pupuk anorganik (4 L larutan induk/50 L air) $+25 \%$ pupuk hayati $(10 \mathrm{~mL}$ dengan kepadatan $\left.1,125 \times 10^{8} \mathrm{CFU} / \mathrm{mL}\right)$, perlakuan $\mathrm{E}=100 \%$ pupuk anorganik (4 L larutan induk/50 L air) + $50 \%$ pupuk hayati $(10 \mathrm{~mL}$ dengan kepadatan $\left.2,25 \times 10^{8} \mathrm{CFU} / \mathrm{mL}\right)$, perlakuan $\mathrm{F}=100 \%$ pupuk anorganik (4 L larutan induk/50 L air) + $75 \%$ pupuk hayati $10 \mathrm{~mL}$ dengan kepadatan $\left.3,375 \times 10^{8} \mathrm{CFU} / \mathrm{mL}\right)$, perlakuan $\mathrm{G}=100 \%$ pupuk anorganik (4 L larutan induk/50 L air) + $100 \%$ pupuk hayati $(10 \mathrm{~mL}$ dengan kepadatan $4,5 \times 10^{8} \mathrm{CFU} / \mathrm{mL}$ ), sehingga terdapat 28 unit percobaan.

Tanaman disemai menggunakan baki selama satu bulan kemudian pada umur 40 hari setelah semai (hss) tanaman dipindahkan ke polybag. Pupuk anorganik diberikan 3 kali sehari. Pada minggu pertama diberikan sebanyak $50 \mathrm{~mL} /$ polybag sesuai dosis yang telah ditentukan pada setiap perlakuan. Setelah satu minggu, volume pupuk anorganik yang diberikan ditingkatkan menjadi 100 $\mathrm{mL} /$ polybag. Setiap satu minggu volume pupuk anorganik yang diberikan ditambah 50 $\mathrm{mL} /$ polybag. Mekanisme pemberian larutan nutrisi menggunakan penyiraman secara manual.

Pertumbuhan tanaman diamati setiap minggu. Data yang diperoleh kemudian dilakukan uji normalitas (Shapiro-Wilk) untuk melihat apakah data menyebar normal atau tidak. Untuk melihat pengaruh perlakuan, data dianalisis menggunakan Uji Fisher (uji F) dan jika ada beda nyata dilakukan uji lanjut jarak berganda Duncan pada taraf nyata $5 \%$.

\section{HASIL DAN PEMBAHASAN}

\section{Gejala Kerusakan Akibat Hama dan Penyakit}

Hama yang ditemukan pada tanaman tomat selama pengamatan di rumah kaca adalah kutu putih atau white flies (Bemisia tabaci). Tanaman yang terserang hama kutu putih akan mengalami perubahan warna pada lamina daun bagian atas menjadi kekuningan, 


\section{JURNAL BIDDJATI}

http://journal.uinsgd.ac.id/index.php/biodjati

sementara bagian bawah tetap berwarna hijau. Hal ini disebabkan oleh kutu putih yang menghisap cairan pada jaringan floem sehingga menyebabkan klorosis pada bagian tersebut (Rahmat, 2013).

Penyakit yang ditemukan pada pengamatan di rumah kaca yaitu embun tepung dan blossom end root. Penyakit embun tepung disebabkan oleh cendawan Oidium sp. yang ditandai dengan adanya lapisan tepung berwarna putih pada bagian atas daun yang terdiri atas konidiofor dan konidium cendawan (Dept. Proteksi Tanaman IPB, 2011). Cara mengatasi penyakit ini yaitu dengan menggunakan ajir tunggal untuk masingmasing tanaman agar sirkulasi udara pada tajuk tanaman lebih baik dan mengurangi kelembaban di sekitar tajuk. Sedangkan penyakit blossom end root disebabkan oleh kekurangan unsur kalsium $(\mathrm{Ca})$ yang ditandai dengan terdapatnya noda busuk pada bagian bawah tanaman. Kalsium yang diserap oleh akar dan dibawa ke bagian atas tanaman oleh jaringan xylem akan terhambat karena banyaknya $\mathrm{Ca}$ pada bagian daun akibat tingginya penguapan, sehingga buah menjadi kekurangan Ca (Fitriani et al., 2017).
Bakteri pelarut fosfat (BPF) merupakan salah satu jenis bakteri Plant Growth Promoting Rhizobacteria PGPR yang berfungsi untuk memicu pertumbuhan tanaman karena menghasilkan hormon pertumbuhan seperti auksin, sitokinin, dan giberelin (Kartikawati et al., 2017), selain itu mampu mengurangi penyakit atau kerusakan oleh serangga (Setiawati et al., 2014). Secara umum pemberian pupuk hayati pada tanaman tomat dengan sistem hidroponik belum menunjukkan perbedaan jumlah populasi bakteri pelarut fosfat dibandingkan tanpa pemberian pupuk hayati (Tabel 1).

Hasil yang tidak berbeda nyata tersebut diduga karena adanya keberadaan mikroba asli habitat (indigen) pada media tanam. Hal tersebut menyebabkan pupuk hayati yang diberikan mengalami persaingan dengan mikroba lain dalam memperoleh nutrisi yang dibutuhkan, sehingga menghambat pertumbuhan bakteri pelarut fosfat (Fitriani et al., 2017). Menurut Simanungkalit et al (2006) aktivitas mikroba dapat terhambat apabila kebutuhan hidup mikroba tersebut tidak terpenuhi sehingga kinerja mikroba akan menjadi kurang optimal.

\section{Populasi Bakteri Pelarut Fosfat}

Tabel 1. Pengaruh pemberian pupuk anorganik dan pupuk hayati terhadap populasi bakteri pelarut fosfat.

\begin{tabular}{lc}
\hline \multicolumn{1}{c}{ Perlakuan } & $\begin{array}{c}\text { Rata-Rata Populasi Bakteri Pelarut } \\
\text { Fosfat }\left(10^{9} \mathrm{CFU} / \mathrm{g}\right)\end{array}$ \\
\hline $\mathrm{A}=100 \%$ pupuk anorganik (kontrol) & 6,56 \\
$\mathrm{~B}=50 \%$ pupuk anorganik $+100 \%$ pupuk hayati & 3,45 \\
$\mathrm{C}=75 \%$ pupuk anorganik $+100 \%$ pupuk hayati & 6,26 \\
$\mathrm{D}=100 \%$ pupuk anorganik $+25 \%$ pupuk hayati & 15,58 \\
$\mathrm{E}=100 \%$ pupuk anorganik $+50 \%$ pupuk hayati & 5,18 \\
$\mathrm{~F}=100 \%$ pupuk anorganik $+75 \%$ pupuk hayati & 4,20 \\
$\mathrm{G}=100 \%$ pupuk anorganik $+100 \%$ pupuk hayati & 4,53 \\
\hline
\end{tabular}




\section{Jurnal Biodjati, 3 (1) 2018

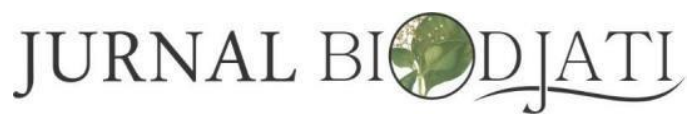

http://journal.uinsgd.ac.id/index.php/biodjati

Keterangan: Angka tidak diberi huruf, karena perlakuan tidak memberikan pengaruh nyata terhadap responmenurut hasil analisis ragam

\section{Kandungan P Tanaman}

Fosfor merupakan unsur hara yang penting bagi pertumbuhan tanaman. Saat berikatan dengan oksigen unsur ini membentuk senyawa fosfat $(\mathrm{P})$. Tanaman menyerap $\mathrm{P}$ dalam bentuk ion fosfat anorganik seperti $\mathrm{H}_{2} \mathrm{PO}_{4}^{-}$dan $\mathrm{HPO}_{4}{ }^{2-}$ (Novriani, 2010). Fosfor dibedakan menjadi dua macam, yaitu Panorganik dan P-organik. P-anorganik berasal dari mineral seperti mineral flour apatit, sedangkan P-organik berasal dari sisa hewan, tumbuhan, dan mikroba. Ketersediaan Porganik pada tanaman sangat bergantung pada aktivitas mineralisasi yang dilakukan oleh mikroba (Stevenson, 1994).

Pemberian pupuk hayati yang dikombinasikan dengan pupuk anorganik menunjukkan tidak berbeda nyata terhadap kandungan $\mathrm{P}$ tanaman tomat dalam sistem hidroponik (Tabel 2). Hal ini dapat disebabkan kurang optimalnya kinerja bakteri pelarut fosfat yang terdapat dalam pupuk hayati yang diberikan pada tanaman. Menurut Illmer dan Schinner (1995, dalam Fitriani, 2017), mekanisme pelarutan fosfat pada media dengan bahan yang sulit larut sering dikaitkan dengan aktivitas mikroba dalam menghasilkan enzim fosfatase. Enzim ini akan dihasilkan dalam kondisi ketersediaan fosfat rendah (Fitriatin et al., 2008). Pada penelitian ini pemberian pupuk anorganik dianggap cukup dalam menyediakan hara bagi tanaman sehingga kinerja mikroba dalam menghasilkan enzim fosfatase menjadi kurang optimal.

Tabel 2. Pengaruh pemberian pupuk anorganik dan pupuk hayati terhadap kandungan fosfat (P) tanaman.

\begin{tabular}{lc}
\hline \multicolumn{1}{c}{ Perlakuan } & $\begin{array}{c}\text { Kandungan } \mathrm{P} \\
(\%)\end{array}$ \\
\hline $\mathrm{A}=100 \%$ pupuk anorganik (kontrol) & 0,271 \\
$\mathrm{~B}=50 \%$ pupuk anorganik + 100\% pupuk hayati & 0,420 \\
$\mathrm{C}=75 \%$ pupuk anorganik + 100\% pupuk hayati & 0,231 \\
$\mathrm{D}=100 \%$ pupuk anorganik + 25\% pupuk hayati & 0,221 \\
$\mathrm{E}=100 \%$ pupuk anorganik + 50\% pupuk hayati & 0,250 \\
$\mathrm{~F}=100 \%$ pupuk anorganik $+75 \%$ pupuk hayati & 0,163 \\
$\mathrm{G}=100 \%$ pupuk anorganik $+100 \%$ pupuk hayati & 0,262 \\
\hline
\end{tabular}

Keterangan: Angka tidak diberi huruf, karena perlakuan tidak memberikan pengaruh nyata terhadap respon menurut hasil analisis ragam.

Tingginya ketersediaan $\mathrm{P}$ menyebabkan pertumbuhan dan aktivitas mikroba pelarut fosfat menjadi kurang optimal. Pemberian pupuk hayati yang mengandung mikroba pelarut fosfat bertujuan untuk meningkatkan ketersediaan $\mathrm{P}$ dan kandungan $\mathrm{P}$ pada tanaman tomat, namun pupuk anorganik yang diberikan mengandung $\mathrm{P}$ terlarut dan tersedia bagi tanaman pada media tanam sehingga pemberian pupuk hayati tidak menunjukkan pengaruh yang nyata karena tanaman telah mendapatkan hara dari media tanam. Oleh 


\section{Jurnal Biodjati, 3 (1) 2018

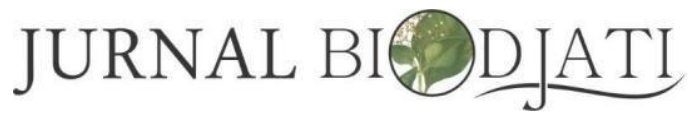

http://journal.uinsgd.ac.id/index.php/biodjati

karena itu peran mikroba pelarut fosfat pada sistem hidroponik bukan untuk meningkatkan kelarutan $\mathrm{P}$ tetapi sebagai penghasil hormon tumbuh pemacu pertumbuhan tanaman (Kartika et al., 2017).

\section{Hasil Tanaman Tomat}

Pemberian pupuk hayati pada tanaman tomat dapat meningkatkan hasil tanaman. Hal tersebut karena mikroba yang terdapat pada pupuk hayati dapat menghasilkan hormonhormon yang meningkatkan pertumbuhan tanaman dan meningkatkan ketahanan tanaman terhadap serangan hama dan penyakit (Kartika et al., 2017). Tabel 3 menunjukkan perbedaan hasil tanaman tomat dengan aplikasi pupuk hayati dan tanpa aplikasi pupuk hayati pada sistem hidroponik.

Tabel 3. Pengaruh pemberian pupuk anorganik dan pupuk hayati terhadap hasil tanaman tomat.

\begin{tabular}{lcc}
\hline \multicolumn{1}{c}{ Perlakuan } & $\begin{array}{c}\text { Rata-Rata } \\
\text { Jumlah } \\
\text { Buah }\end{array}$ & $\begin{array}{c}\text { Rata-Rata } \\
\text { Bobot Buah } \\
(\mathrm{g})\end{array}$ \\
\hline $\mathrm{A}=100 \%$ pupuk anorganik (kontrol) & 25,00 & 1194,25 \\
$\mathrm{~B}=50 \%$ pupuk anorganik + 100\% pupuk hayati & 25,00 & 1668,00 \\
$\mathrm{C}=75 \%$ pupuk anorganik + 100\% pupuk hayati & 21,75 & 1297,50 \\
$\mathrm{D}=100 \%$ pupuk anorganik + 25\% pupuk hayati & 23,50 & 1482,00 \\
$\mathrm{E}=100 \%$ pupuk anorganik + 50\% pupuk hayati & 23,75 & 1443,00 \\
$\mathrm{~F}=100 \%$ pupuk anorganik $+75 \%$ pupuk hayati & 23,50 & 1386,25 \\
$\mathrm{G}=100 \%$ pupuk anorganik $+100 \%$ pupuk hayati & 29,00 & 1628,00 \\
\hline
\end{tabular}

Keterangan: Angka tidak diberi huruf, karena perlakuan tidak memberikan pengaruh nyata terhadap respon menurut hasil analisis ragam.

Berdasarkan hasil analisis ragam pada Tabel 3 menunjukan bahwa pemberian pupuk hayati pada tanaman tomat dengan sistem hidroponik tidak memberikan pengaruh yang nyata terhadap hasil tanaman tomat. Menurut Astari et al (2013) kondisi ini dapat terjadi karena tanaman telah memperoleh hara yang cukup dari larutan nutrisi pupuk anorganik yang bersifat tersedia dan mudah diserap oleh tanaman sehingga efektivitas penggunaan pupuk hayati kurang terlihat. Namun hasil tanaman yang diberikan pupuk hayati cenderung menunjukan hasil yang lebih baik dibandingkan tanpa pemberian pupuk hayati. Hal ini disebabkan mikroba yang terdapat pada pupuk hayati menghasilkan zat-zat pengatur tumbuh yang mempercepat pertumbuhan tanaman (Husna, 2013). Hormon-hormon pertumbuhan yang dihasilkan oleh mikroba pada pupuk hayati yaitu hormon auksin, sitokinin, dan giberelin (Antonius et al., 2014). Pupuk hayati juga mengkolonisasi perakaran tanaman yang mempengaruhi perpanjangan akar tanaman (Blanco dan Bakker, 2007) sehingga penyerapan nutrisi menjadi lebih baik.

Kesimpulan dari penelitian ini yaitu pupuk anorganik yang dikombinasikan dengan pupuk hayati dalam sistem hidroponik memberikan pengaruh yang tidak berbeda nyata terhadap populasi bakteri pelarut fosfat, kandungan fosfat $(\mathrm{P})$, serta hasil tanaman tomat. Oleh karena itu diperlukan penelitian lebih lanjut dengan mengurangi unsur hara yang berhubungan dengan parameter penelitian yaitu unsur fosfat $(\mathrm{P})$ pada pupuk 


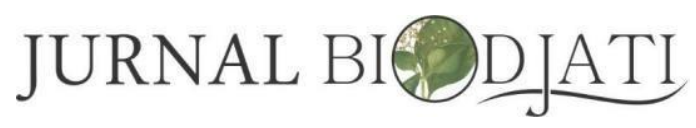

http://journal.uinsgd.ac.id/index.php/biodjati

anorganik agar diperoleh hasil yang signifikan terhadap populasi bakteri fosfat, kandungan $\mathrm{P}$

\section{UCAPAN TERIMA KASIH}

Penulis mengucapkan terimakasih kepada Universitas Padjadjaran yang telah mendanai penelitian ini melalui Skema Penelitian Prioritas Unpad 2017.

\section{DAFTAR PUSTAKA}

Antonius, S., Agustyani, D., Antonius, Imamuddin, Dewi, \& Laili. (2014). Kajian Bakteri Penghasil Hormon Tumbuh IAA Sebagai Pupuk Organik Hayati dan Kandungan IAA selama Penyimpanan (Diakses pada tanggal 3 Maret 2018, http://balittro.litbang.pertanian.go.id/wpcontent/uploads/2015/10/35-SarjiyaKajian-Bakteri-Penghasil-Hormon.pdf.) Astari, W., Purwani, K. I., \& Anugerahani, W. (2014). Produktivitas Tanaman Tomat ( Solanum lycopersicum L.) Var. Tombatu di PT Petrokimia Gresik. Jurnal Sains Dan Seni Pomits, 2(1), 2-5.

Basuki, T.A. (2008). Pengaruh Macam Komposisi Hidroponik terhadap Pertumbuhan Hasil Selada (Lactuca sativa L.). Skripsi. Yogyakarta: Fakultas Pertanian Universitas Gadjahmada.

Blanco, \& Baker. (2007). Interaction Between Plant and Beneficial Pseudomonas spp: Exploiting Bacterial Traits for Crop Protection. (Rev. 92). Hh. 367-389.

Departemen Proteksi Tanaman IPB. (2011). Embun Tepung. (Diakses pada tanggal 14 Januari 2018 dari http://www. opete.info/detail2.php?idp=745)

Ekaputri, N. (2008). Harvested Area Influence to Production of Food and Estate Crops in tanaman, serta hasil tanaman tomat dengan sistem hidroponik.

East Kalimantan. Pengaruh Luas Panen Terhadap Produksi Tanaman Pangan Dan Perkebunan Di Kalimantan Timur, 5(2), 36-43.

Ermina. (2010). Media Tanaman Hidroponik dari Arang Sekam (Diakses pada tanggal 8 Januari 2018 dari http://www.bbpplembang.info/index.php/arsip/artikel/artike 1-pertanian/503-media-tanamanhidroponik-dari-arang-sekam).

Fitriatin, B.N., Yuniarti, A., Mulyani, O., Fauziah, F.S., \& Tiara, M.D. (2009). Pengaruh Mikroba Pelarut Fosfat (MPF) dan Pupuk $\mathrm{P}$ terhadap $\mathrm{P}$ Tersedia, Aktivitas Fosfatase, P Tanaman dan Hasil Padi Gogo (Oryza sativa L.) pada Ultisol. Jurnal Agrikultura, 20 (3): 210-215.

Herlina, N., Fitriani, W., Kunci, K., Jagung, :, Daun, P., \& Jantan, P. B. (2017). Pengaruh Persentase Pemangkasan Daun Dan Bunga Jantan Terhadap Hasil Tanaman Jagung (Zea mays L.). Jurnal Biodjati, 2(2).

Husna. (2013). Pemanfaatan Pupuk Hayati (Pseudomonas flourescens) untuk Meningkatkan Efisiensi Pemupukan pada Tanaman Tomat. Skripsi. Lampung: Fakultas Pertanian Universitas Lampung.

Kartika. E., Yusuf, R. \& Syakur, A. (2015). Pertumbuhan dan Hasil Tanaman Tomat (Lycopersicum esculentum Mill.) pada Berbagai Persentase Naungan. Jurnal Agrotekbis, 3 (6), 717-724.

Kartikawati, A., Trisilawati, O., \& Darwati, I. (2017). Pemanfaatan Pupuk Hayati (Biofetilizer) Pada Tanaman Rempah dan Obat. Jurnal Prespektif, 16(1), 33-43.

Kementrian Pertanian. (2015). Produksi Tomat Menurut Provinsi. (Diakses pada tanggal 3 


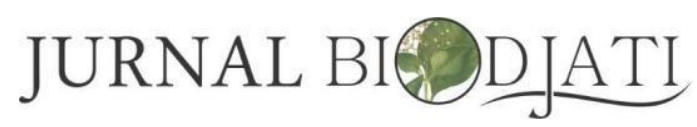

http://journal.uinsgd.ac.id/index.php/biodjati

Mei 2017 dari http://www. pertanian.go.id/ap_pages/mod/datahorti).

Lingga, P. (2009). Hidroponik: Bercocok Tanam Tanpa Tanah (Edisi Revisi). Jakarta: Penebar Swadaya.

Listiana, N., Nawawi, \& Wardiyati. (2010). Pengaruh Media Tanam dan Pupuk SP 36 terhadap Pertumbuhan Tanaman Gladiol (Gladiolus hybridus L.). Jurnal Buana Sains, 10 (2), 47-152.

Marliah, A., Hayati, M., \& Muliansyah, I. (2012). Pemanfaatan Pupuk Organik Cair Terhadap Pertumbuhan Dan Hasil Beberapa Varietas Tomat (Lycopersicum esculentum L.). Jurnal Agrista, 16(3), 122-128.

Masfufah, A., Supriyanto, A., \& Surtiningsih, T. (2015). Pengaruh Pemberian Pupuk Hayati (Biofertilizer) pada Berbagai Dosis Pupuk dan Media Tanam yang Berbeda terhadap Pertumbuhan dan Produkivitas Tanaman Tomat (Lycopersicon esculentum) pada Polybag (Diakses pada tanggal 15 Januari 2018 dari http://journal.unair.ac.id/downloadfullpapers-biologif889051352full.pdf)

Novriani. (2010). Alternatif Pengelolaan Unsur Hara P (Fosfor) pada Budidaya Jagung. Jurnal Agronobis, 2 (3): 42-49.

Rahmat. (2013). Kutu Kebul/Kutu Putih (Bemisia tabaci) (Diakses pada tanggal 12
Januari 2018, dari http://www. taniorganik.com/kutu-kebulkutu-putihbemisia-tabaci/).

Sastrosiswojo, S., Uhan, \& Sutarya. (2005). Penerapan Teknologi PHT pada Tanaman Kubis. Bandung: Balai Penelitian Tanaman Sayuran.

Setiawati, M.R., Suryatmana, P., Hindersah, R., Fitriatin, B.N. dan Herdiyantoro, D. (2014). Karakterisasi Isolat Bakteri Pelarut Fosfat untuk Meningkatkan Ketersedian P pada Media Kultur Cair Tanaman Jagung (Zea mays L.). Bionatura - Jurnal Ilmu-Ilmu Hayati dan Fisik, 16(1), 30-34.

Simanungkalit, R. D. M, Surdiakarta, Saraswati, Setyorini, \& Hartatik. (2006). Pupuk Organik dan Pupuk Hayati (Diakses pada tanggal 8 Januari 2018 dari http://balittanah.litbang.pertanian.go.id/ind /index.php/berita-terbaru-topmenu58/563-hayati121).

Stevenson, F.J. (1994). Humus Chemistry: Genesis, Composition, Reactions. ( $\left.2^{\text {nd }} \mathrm{ed}\right)$. New York: Wiley.

Wasonowati, C. (2011). Meningkatkan Pertumbuhan Tanaman Tomat (Lycopersicon esculentum Mill) dengan Sistem Budidaya Hidroponik. Madura: Fakultas Pertanian Universitas Trunojoyo. 